\title{
Presessie 2
}

De agenda van deze sessie bestaat uit de volgende punten:

- Afmaken van de eigen situaties

- Eigen situaties meegeven

In deze sessie is er tijd om de eigen situaties uit de vorige sessie af te maken. Geef aan het eind van de sessie deze eigen situaties mee aan de cliënt (zie bijlage 2 achter in het werkboek voor de cliënt). 